\title{
BIAS PENERAPAN DELIK ADUAN DALAM PASAL 207 KUHP TENTANG PENGHINAAN TERHADAP PENGUASA (Studi Kasus Putusan No.1274/Pid.Sus/2017/Pn.Jkt.Sel)
}

\author{
Litya Surisdani Anggraeniko \\ UIN Sunan Gunung Djati Bandung/Pascasarjana/Ilmu Hukum \\ Email : "lityasurisdania@gmail.com
}

\begin{abstract}
Abstrak
Mahkamah Konstitusi dalam pertimbangan putusannya No.013-022-2006 menyatakan bahwa dalam Pasal 207 KUHP seharusnya diterapkan delik aduan, hal demikian bertujuan untuk mencegah multi tafsir atas sebuah kritik yang berpeluang melanggar hak kebebasan berekpresi serta untuk mencegah adanya ketidakpastian hukum dalam negara hukum yang demokratis. Penelitian ini bertujuan mengetahui pelaksaan delik aduan dalam Pasal 207 KUHP serta analisis putusan dalam putusan No.1274/Pid.Sus/2017/PN.Jkt.Sel. Metode penelitian ini menggunakan desktiptif-analisis dengan pendekatan yuridis-empiris serta jenis data kualitatif. Hasil penelitian menunjukan bahwa tidak diterapkannya delik aduan dalam Pasal 207 KUHP atas dasar kepastian hukum. Bahwa hukum pidana merupakan hukum yang menjamin hak-hak kebebasan individu didalamnya, maka dewasa ini dengan adanya putusan Mahkamah Konstitusi telah terjadi pembaharuan hukum pidana di Indonesia, terutama dalam penerapan delik Pasal 207 KUHP.
\end{abstract}

Kata kunci: Delik Aduan, Penghinaan Penguasa, Hak Bereskpresi, Mahkamah Konstitusi

\section{Abstract}

The Constitutional Court in its consideration of decision No.013-022-2006 states that in Article 207 of the Criminal Code there should be an offense of complaint, it aims to prevent multiple interpretations of a critique that has the potential to violate the right to freedom of expression and to prevent legal uncertainty in a democratic rule of law. This study aims to determine the implementation of complaint offenses in Article 207 of the Criminal Code and analysis of decisions in the decision No.1274 / Pid.Sus / 2017 / PN.Jkt.Sel. This research method uses descriptive analysis with a juridical-empirical approach and qualitative data types. The results of the study showed that the complaint was not applied in Article 207 of the Indonesian Criminal Code based on legal certainty. Whereas criminal law is a law that guarantees the rights of individual freedom in it, so today with the decision of the Constitutional Court there has been a renewal of criminal law in Indonesia, especially in the application of Article 207 of the Criminal Code.

Keyword : Complaints and complaints, insults from the authorities, the right to expression, the Constitutional Court 


\section{A. PENDAHULUAN}

Salah satu bentuk dukungan dalam menciptakan sistem nasional yang dicitacitakan adalah terkait dengan penegakan hukum yang mana merupakan sebuah proses yang harus dilaksanakan sesuai dengan peraturan perundang-undangan yang berlaku dengan tidak melupakan budi nurani sebagai manusia disertai itikad baik untuk membangun masyarakat yang berbudaya hukum. Konkritisasi dalam hal penegakan hukum sering dikaitkan dengan penegakan hukum yang ada dalam hukum pidana, yang seharunya menjadi cara represif untuk menanggulangi tindak pidana dalam hal ini adalah pencemaran nama baik maupun penghinaan yang menggunakan delik sesuai dengan ketentuan hukum yang mengatur. Berkaitan dengan Pasal 207 KUHP yang menyatakan "Barang siapa dengan sengaja dimuka umum dengan lisan atau tulisan menghina suatu penguasa atau badan umum yang ada di Indonesia, diancam dengan pidana penjara paling lama satu tahun enam bulan atau denda paling banyak tiga ratus rupiah".

Dalam sejarahnya Pasal ini tidak termasuk dalam delik-delik khusus, namun kemudian dalam Putusan Mahkamah Konstitusi No._013-022-2006 dan 31/PUU-XIII-2015 pada Desember 2015 menyatakan secara implisit bahwa Pasal 207 KUHP dinyatakan sebagai delik aduan, setiap putusan Mahkamah Konstitusi memiliki sifat mengikat sehingga harus dijalankan karena sifat putusannya final pula sebagai penghormatan peradilan di Indonesia, termasuk dalam hal ini penegak hukum pelaksana yang tujuannya adalah melindungi warga negara dan memberikan kepastian hukum.
Mahkamah Konstitusi secara implisit menyatakan bahwa ketentuan-ketentuan tentang penghinaan terhadap pemerintah yang sah dapat menimbulkan ketidakpastian hukum karena amat tergantung pada tafsir apakah suatu protes, pernyataan pendapat atau pikiran, suatu kritik atau penghinaan, serta abstraksi yang berpeluang menghambat hak atas kebebasan menyatakan pikiran dengan lisan, tulisan, dan ekspresi sikap.

Oleh karena itu, penggunaan ketentuan pidana dalam hal penghinaan terhadap pemerintah dan/atau pejabat pemerintah yang sah harus dihindari oleh aparat penegak hukum. Penegakan hukum oleh aparat penegak hukum pemerintahan berdasarkan hukum bukan sekadar penegakan hukum, melainkan upaya negara membangun sistem hukum yang bekerja secara berkeadilan, tanpa diskriminasi, dan menjangkau seluruh struktur politik ketatanegaraan untuk menjamin hak dasar warga negara. Ketiadaan komitmen politik yang kuat dari pemerintah melakukan perubahan "menjadi lebih maju" merupakan alasan nyata pelanggaran terhadap hak warga negara hingga kini masih berlangsung.

Terkait penerapkan delik aduan selain pada kasus penghinaan terhadap peguasa terdapat pula pada kasus perzinahan, penghinaan terhadap Presiden, pencemaran nama baik yang merupakan delik aduan lainnya4. Tetapi, putusan Mahkamah Konstitusi tersebut sering kali tidak diindahkan oleh aparat penegak hukum pada kasus penghinaan dalam hal ini adalah penghinaan terhadap penguasa,hal demikian dapat 
menjadi indikator dari pembangkangan konstitusi. ${ }^{1}$

Persoalan mendasar terkait dengan delik penghinaan dalam Pasal 207 KUHP terkait dengan proteksi terhadap penguasa, dalam pembuktian persidangan, menjadi memberatkan, ketentuan tersebut sangat mudah ditafsirkan secara meluas adapun yang harus dibuktikan unsur Pasal adalah sebagai berikut: ${ }^{2}$

1. Niat dan kesengajaan untuk menghina, dalam Pasal 207 KUHP disebutkan frasa "niat kesengajaan untuk menghina" bahwa dalam hal ini harus dapat dibuktikan secara jelas tersangka memiliki niat untuk menghina dan sengaja melakukan hal tersebut, ini akan akan sulit karena akan melibatkan nurni

2. Tujuan pernyataan, bahwa kata-kata yang ditulis atau dilontarkan oleh pelaku harus dapat dibuktikan merupakan suatu penghinaan bukan suatu kritik wajib dibuktikan kembali karena rentan subjektivitas individu dalam tafsirannya artinya yang digunakan nantinya adalah subjetif yang diobjektifiksir, kelemahan dimana pelaksanaan delik penghinaan pada umumnya selalu dalam keadaan tidak seimbang antara si penghina dan terhina yang lazimnya posisi, si terhina selalu dalam posisi yang lebih kuat baik secara ekonomi, politik ataupun hukum dari yang menghina.

3. persoalan pokok dalam memandang delik penghinaan yaitu adanya hubungan yang sistemik antara

1 Ni'matul Huda, Kekuatan Eksekutorial Putusan Mahkamah Konstitusi, FH UII Press, Yogyakarta, 2018 .202.

2 ELSAM, ICJR, IMDLN, PBHI dan YLBHI, Pidana Penghinaan adalah Pembatasan Kemerdekaaan Berpendapat yang Inkonstitusional, Brefing Paper No.2, 2010, .39. rumusan norma yang kabur dengan pelaksanaan dari norma tersebut, dan pada akhirnya membuat para hakim secara konsisten telah melakukan pelaksanaan yang merugikan hak-hak konstitusional dari warga negara. Persoalan yang ada dalam norma tersebut adalah terletak pada rumusan unsur-unsur yang sifatnya "karet", sehingga tidak memenuhi prinsip lex certa dalam suatu perumusan delik pidana.

Bahwa dalam rangka penegakan hukum pidana yang merupakan jaminan kepastian hukum, ketertiban dan perlindungan hukum oleh aparat penegak hukum sebagai upaya untuk masyarakat yang beradab agar tercipta keselarasan, keseimbangan, dan keserasian dalam penegakan hukum pidana sebagai sistem peradilan pidana yang bertujuan melindungi hak-hak individu yang sering disebut HAM. ${ }^{3}$

Oleh karena itu dalam paham Negara hukum, jaminan HAM dianggap ciri mutlak dalam sebuah Negara demokrasi. Jaminan kemerdekaan menyatakan pikiran dan pendapat, kebebasan berekspresi, dan kemerdekaan pers telah dinyatakan secara ekplisit, namun tak kurang banyak kasus yang menjerat warga negara Indonesia saat menyatakan pendapatnya secara lisan dan tulisan berujung didalam bui. Dewasa ini transisi demokrasi dan konsolidasi demokrasi secara bersamaan menguat ke permukaan.

Pembahasan HAM dalam konteks sistem peradilan pidana (criminal justice system) yang berada dalam jaringan sistem peradilan yang mendayagunakan hukum pidana serta hak, kewajiban dan

${ }^{3}$ Mardjono Reksodiputro, Sistem Peradilan Pidana Indonesia, Pusat Keadilan dan Pengabdian Hukum UI, Jakarta, 1993, .17. 
etika penguasa dalam memperlakukan pelaku tindak pidana, sanksi dan korban, pelbagai pembatasan terhadap kekuasaan negara sebagai usaha menciptakan keseimbangan terhadap efisiensi dalam pencegahan dan penanggulangan kejahatan jaminan terhadap hak-hak individual.

Dihubungkan dengan hukum pidana terdapat beberapa aturan terkait dengan pengaturan proteksi penguasa negara yang berbenturan dengan HAM hal tersebut terutama diatur dalam buku II KUHP berisi empat bab yang mengatur staatkundige misdrijven atau kejahatan ketatanegaraan, salah satu bentuk kejahatan ketatanegaraan adalah kejahatan terhadap kekuasaan umum sebagaimana diatur dalam Pasal 207-233 BAB IV KUHP. Pelaksanaan Pasal proteksi penguasa di Indonesia dalam praktiknya, sering disalahgunakan untuk merendam dan menghilangkan kebebasan politik dan ekspresi bagi warga negara. Penghilangan hal tersebut, terutama ditunjukan bagi warga negara yang berpendapat tidak sesuai atau bertentangan dengan kepentingan Negara. Artinya proteksi penguasa dalam KUHP sering dijadikan alat kriminalisasi bagi individu atau kelompok yang kritis terhadap kepentingan pemerintah, hal demikian tentu saja mengancam hak asasi manusia juga demokrasi.

Terkait dengan hal ini dapat dibuktikan dengan adanya perkara Pidana putusanNo.1274/Pid.Sus/2017/PN.Jkt.Se 1 yang menjerat Asma Dewi dengan dakwaan alternatif Jaksa Penuntut Umum dantaranya adalah Pasal 28 ayat (2) jo Pasal 45 ayat (2) undang-undang No.19 Tahun 2016 Tentang Informasi dan Transaksi Elektronik, Pasal 16 jo Pasal 4 huruf b angka (1) undang- undang No.40 Thaun 2008 Penghapusan diskriminasi dan etnis, Pasal 156 KUHP dan terkahir masalah dalam Pasal 207 KUHP, Kemudian Hakim mengabulkan dakwaan keempat yang duduk perkaranya adalah re-posting Asma Dewi terkait dengan berita yang ada pada media elektonik dengan menambahkan komentar "koplak dan edun" yang ditunjukan kepada Pemerintah. Hal ini memiliki beberapa analisa terhadap beban pembuktian atas dakwaan yang menjeratnya serta penggunaan Pasal 207 KUHP sebagai pertimbangan delik yang telah digunakan.

\section{B. METODE PENELITIAN}

Penelitian ini menggunakan metode penelitian deskriptif-analisis yaitu penelitian yang memberikan gambaran sistematis terkait dengan Pasal 207 KUHP dan Putusan Mahkamah Konstitusi No. 013-022-2006 dengan pendekatan yuridis-empiris atau disebut sebagai penelitian hukum sosiologis dengan studi kasus No.1274/Pid.Sus/2017/PN, serta menggunakan jenis data kualitatif yaitu dengan memberikan gambaran menggunakan kata-kata dengan analisis data dari hasil penelitian kepustakaan, wawancara serta dokumentasi terkait dengan penerapan delik aduan.

\section{HASIL PENELITIAN}

PutusanNo.1274/Pid.Sus/2017/PN.Ja ksel mengadili perkara pidana dengan terdakwa atas nama Asma Dewi. Bahwa terdakwa merupakan target yang sebelumnya pernah mencatatkan diri sebagai orang yang di duga bergabung dengan Saracen. Dalam operasi patroli Direktorat Tindak Pidana Siber Bareskim Polri menemukan akun facebook atas nama Asma Dewi Ali Hajim dan Asma Dewi, didalamya 
terdapat gambar dan tulisan yang bermuatan kebencian atau permusuhan yang mengandung SARA.

Profiling yang dilakukan oleh siber polri merupakan pendalaman terhadap akun untuk mencari konten yang mengandung unsur pidana. Selain itu di lakukan pula digital forensik dalam hal ini adalah metode ilmiah dari ilmu forensik untuk melakukan pengumpulan, analisa, pemulihan data yang berasal dari elektronik. Bahwa salah satu postingannya terkait dengan akun terdakwa menyebarkan video dari Primetime News tayangan Metro TV dengan judul "mentan yakin impor jeroan stabilkan harga" dengan komentar "edun", selanjutnya diposting kembali dengan akun terdakwa lainnya dengan komentar "rezim koplak di luar negeri dibuang disini disuruh makan rakyatnya".

Postingan ini semestinya kembali harus dibuktikan terhadap pelaku, dalam dokmatif hukum perkataan seseorang harus mewujudkan motif. Motif bukanlah suatu unsur tetapi dapat digunakan untuk mempertegas apakah perbuatan itu dilakukan dengan sengaja atau tidak. R Soesilo menyatakan bahwa kekuasaan harus disebutkan organ yang nantinya berkaitan dengan subjek atau objek hukum dalam perkara ini.

Biasnya pembedaan antara kritik dan menghina menjadi faktor utama dalam hal ini, keduanya sangatlah dekat tetapi memiliki makna yang jauh berbeda. Menghina adalah suatu perbuatan tindak pidana karena penghinaan merupakan kesengajaan untuk menyerang kehormatan atau nama baik seseorang yang diawali dengan adanya kesengajaan jahat atau niat jahat (criminal intent) agar orang lain terserang kehormatan nama baiknya.
Sehingga putusan Mahkamah Konstitusi tidak diindahkan oleh Majelis Hakim Pengadilan Negeri Jakarta Selatan, yang seharusnya meninjau kembali penerapan Pasal dakwaan yang digunakan oleh Jaksa Penuntut Umum sesuai dengan pada perkara ini hanya dilakukan profiling - penyelidikan penyidikan - penuntutan, tanpa adanya laporan dari pihak yang merasa dirinya dirugikan.

Berdasarkan uraian di atas maka penulis berpendapat, dalam hal ini seharusnya penerapan delik dalam Pasal 207 KUHP tentang penghinaan terhadap penguasa adalah delik aduan sesuai dengan putusan Mahkamah Konstitusi No.013-022-2006. Namun, pelaksanaan dalam delik dalam kasus putusan PN No.1274/Pid.Sus/2017/PN.Jaksel tidak diterapkan dan dilaksanakan. Putusan hakim adalah putusan dalam rangka melaksanakan tugas pokok pengadilan yaitu menerima, memeriksa dan mengadili sesuai dengan Pancasila dan UUD NRI Tahun 1945.

Dalam upaya mewujudkan rekonstruksi lembaga pengadilan menuju sistem peradilan pidana yang mandiri dan bertanggungjawab maka seharusnya dilakukan pemisahan kekuasaan yudikatif dan eksekutif, perbaikan kesejahteraan komponen pengadilan, pembentukan komisi yustisial, penyempurnaan kewenangan dan susunan organisasi serta upaya reformasi peraturan hukum. Selanjutnya terdapat upaya revitalisasi lembaga peradilan dengan melakukan peningkatan kausalitas teoritis, kesadaran dan tanggungjawab, kemandirian lembaga serta perbaikan moral komponen.

Jika dihubungkan dengan putusan hakim terhadap kasus No.1274/Pid.Sus/2017/PN.Jaksel telah sesuai dengan dua pertimbangan hakim 
terkait pertimbangan yuridis sesuai dengan Pasal Pasal 193 ayat (3) KUHAP. Tetapi dalam pertimbangan tersebut tidak memuat adanya pertimbangan yang bersifat non-yuridis.

Jika perbuatan yang didakwakan kepada terdakwa bukan delik (tindak pidana), maka sejak permulaan seharusnya hakim tidak menerima tuntutan jaksa sejalan dengan frasa "tetapi" dalam Pasal 191 ayat (2) KUHP. ${ }^{4}$ Majelis berpendapat bahwa koplak dan edun tidak termasuk dalam kritik serta tidak termasuk dalam Kamus Besar Bahasa Indonesia. Koplak bisa mempunyai banyak arti, dapat diartikan bodoh, dungu, aneh, otak miring sebelah. Sedangkan, edun menurut hemat majelis adalah plesetan dari kata edan. Ari Laksono selaku penasehat hukum terdakwa mengatakan Majelis Hakim sepakat dengan posisi Indonesia sebagai negara demokrasi dan warga negara memberikan kritik. Hanya majelis berpikir dalam posisi kalimat kata-kata edun dan kata-kata koplak yang masih jadi argumentasi antara pihak terdakwa dengan majelis. Bahwa menurutnya yang dilakukan kliennya merupakan kritik terhadap pemerintah.

Namun disisi lain bahwa Mahkamah Konstitusi merupakan negative legislator yang artinya Mahkamah hanya dapat membatalkan norma tidak dapat disamakan dengan kewenangan legislative. Jadi Mahkamah hanya terbatas memutus bahwa pasal-pasal yang di judicial review tidak memiliki kekuatan hukum mengikat atau dengan kata lain dekriminalisasi pasal yang ada dalam KUHP. Mahkamah Konstitusi tidak memutus bahwa Pasal 207 KUHP adalah delik aduan, hal tersebut hanya ada dalam pertimbangan yang bisa

4 Andi Hamzah, Hukum Acara Pidana Indonesia, Sinar Grafika, Jakarta, 2014, .288 diambil dimasa yang akan datang agar legislator mengubah atau menambahkan aturan terkait Pasal 207 KUHP sebagai delik aduan. Bahwa yang menjadi acuan dalam hal ini adalah amar putusan Mahkamah Konstitusi bukan pertimbangan, karena kedudukan petimbangan hanya mendukung terbentuknya amar putusan.

Hakim dalam hal ini memberikan pertimbangan bahwa telah menjadi fakta hukum terdakwa didepan persidangan karena konten atau tulisan terdakwa dari unggahan terkait "rezim koplak" dan "edun". Dalam hal ni dapat diartikan rezim adalah tata pemerintahan negara atau pemerintahan negara, komentar terdakwa dalam hal ini bukanlah suatu kritik, karena kritik yang baik yang sifatnya membangun bukanlah dengan kata tersebut yang dapat dikatagorigakan menghina dan Pasal ini memberikan jaminan alat-alat kekuasaan negara tetap dihormati; Menimbang dari pertimbangan-pertimbangan tersebut majelis hakim berpendapat bahwa unsur inipun telah terpenuhi, sehingga karena semua unsur Pasal 207 KUHP telah terpenuhi, maka terdakwa haruslah dinyatakan telah terbukti secara sah dan meyakinkan melakukan tindak pidana sebagaimana yang telah didakwakan dalam dakwaan alternatif. Kemudian terhadap pledoi dari penasehat hukum khususnya tentang dakwaan keempat tersebut yaitu tentang adanya putusan Mahkamah Konstitusi No.013022/PUU-IV/2006 ternyata putusan tersebut adalah mengenai Pasal 134, Pasal 136 bis dan Pasal 137 KUHP. Sehingga pledoi penasehat hukum terdakwa patutlah dikesampingkan.

Melihat kondisi saat ini hakim memang menerapkan konsep positivis yang kurang relevan dengan kondisi sekarang, sehingga meninggalkan kesan 
terlalu mengejar kepastian hukum dan mengenyampingkan kemanfaatan hukum itu sendiri yang menyebabkan putusan tersebut tidak adil. Berdasarkan uraian di atas penulis berpendapat bahwa dalam putusan hakim Pengadilan Negeri Jakarta Selatan No.1274/Pid.Sus/2017/PN.Jaksel adalah hakim tidak mengindahkan putusan Mahkamah Konstitusi dengan menolak pledoi dari penasehat hukum, dalam hal pembuktian hakim belum dapat memisahkan antara menghina dengan kritik. Dalam hal pertimbangan hukum dan putusannya hakim seharusnya menerapkan konsep hukum untuk masyarakat, bukan masyarakat untuk hukum.

Dalam kepastian hukum telah dijelaskan bahwa hukum tetaplah instrumen yang adil dan demokratis, yang merupakan sarana digunakan dengan situasi dan kondisi dengan memperhatikan manfaat bagi masyarakat dan merupakan wujud dari adanya negara hukum.

Pemaknaan kepastian hukum tidak dapat dianggap sebagai elemen semata, yang mutlak setiap saat. Konsep delik aduan dapat dimaknai bahwa suatu perbuatan memiliki konsekuensi hukum ketika tidak adanya aduan korban kepada aparat penegak hukum, terdapat kerugian yang ditimbulkan ketika delik dalam Pasal 207 KUHP bukan aduan adalah dapat merusak citra korban itu sendiri, korban penghinaan dalam hal ini penguasa atau pejabat yang sedang menjalankan tugasnya, sebenarnya dapat merasa tidak dirugikan dan bersedia untuk memaafkan. dalam putusan Mahkamah Konstitusi No.013-022-2006 dan 31/PUU-XIII-2015 pada Desember 2015 menyatakan secara implisit dan eksplisit dalam pertimbangan bahwa
Pasal 207 KUHP dinyatakan sebagai delik aduan.

Bahwa tidak relevan untuk membedakan pengaturan bahwa penghinaan kepada anggota masyarakat secara umum merupakan delik aduan sementara terhadap penguasa merupakan bukan delik aduan, perbedaan demikian tidak sesuai dengan cita-cita kemerdekaan bangsa Indonesia untuk mencapai kedudukan manusia yang sederajat dan berkeadilan. Terdapat putusan Mahakamah Konstitusi lain yang menguatkan pendapat bahwa penerapakan delik dalam Pasal 207 KUHP adalah delik aduan pada Putusan Mahkamah Konstitusi No.14/PUU$\mathrm{VI} / 2008$.

Telah jelas bahwa Pasal 207 KUHP merupakan delik aduan yang masuk dalam delik aduan absolut sehingga perbuatan dan orang yang melakukan perbuatan itu dianggap satu kesatuan yang bermuara pada kejahatan yang dilakukan $^{5}$, sehingga ketika tidak adanya aduan dari korban dalam hal ini penguasa adalah menjadi bertentangan dengan aturan hukum yang ada. Akibat hukum dari tidak adanya aduan dari korban adalah salah satunya hapusnya hak menuntut oleh Jaksa Penuntut Umum.

Pasal-pasal penhginaan seperti yang dimuat dalam Pasal 310 KUHP, 311 KUHP dan kini 207 KUHP masuk dalam golongan yang memiliki kesamaan dalam perbuatan yang dilakukan oleh semua orang, tidak untuk profesi tertentu. Sehingga amatlah jelas bahwa pemberlakuan delik dalam Pasal 207

\footnotetext{
5 Valerian Itu Varis, Delik aduan dalam pasal penghinaan ITE, Diakses Melalui: <https://www.kompasiana.com/valerianlibertwangge/ 58173faccb23bd7c33e64370/delik-aduandalampasal-penghinaan-uu-ite?page $=$ all $>$, Diunduh Pada $\begin{array}{lllll}\text { Tanggal } & 12 & \text { Februari 2019, Pukul } 7.24\end{array}$ WIB.
} 
KUHP adalah delik aduan. Dalam konteks negara demokrasi penting mempertanyakan relevansi adanya pemberian sanksi pidana dengan kasus pencemaran nama baik, bahwa terdapat dalil penting dalam hukum pidana yaitu ultimum remedium (upaya terakhir) efektivitas penegakan hukum pidana dalam kasus penghinanaan khususnya pada penghinanaan terhadap penguasa menemui kendala yakni terkait dengan pembuktian dari unsur kesengajaan dan niat tujuan apakah menghina atau mengkritik.

Salah satu fungsi hukum adalah menertibkan dan memecahkankonflik. Dalam hal ini hukum dapat diartikan pengadilan baru akanberoperasi setelah adanya suatu konflik, seseorang mengklaim bahwakepentingankepentingannya telah diganggu oleh orang lain. Tugas pengadilan adalah membuat suatu putusan yang akan mencegah adanya suatu konflik dan gangguan mewujudkan terciptanya kerjasama. Pengadilan bergantung pada 3 (tiga) jenis tempat, pertama pengadilan membutuhkan suatu analisis tentang hubungan sebab-akibat, kedua pembagian kerja dan ketiga adalah melaksanakan fungsinya pengadilan membutuhkan suatu kemauan dari para pihak untuk menggunakan pengadilan sebagai mekanisme penyelesaian konflik sebagai apa yang dinamakan sistem pattern-maintenance (mempertahankan pola) adalah apa yang akan dinamakan suatu "keadilan" oleh pengadilan. ${ }^{6}$

Satu kesatuan struktur putusan Mahkamah Konstitusi merupakan tidak dapat dipisahkannya antara amar dan pertimbangan, maka putusan Mahkamah Konstitusi yang dalam hal ini putusan dalam perkara pengujian undang-undang

\footnotetext{
${ }^{6}$ Achmad Ali, Wiwie Haryani, Resep Hukum, Kencana, Jakarta, 2012, .135
}

terhadap UUD memiliki kekuatan hukum mengikat. Penjelasannya bahwa Putusan Mahkamah Konstitusi dalam proses pengujian undang-undang terhadap Undang-Undang Dasar adalah merupakan pernyataan pengadilan yang mengakhiri dan menyelesaikan perselisihan yang diajukan tentang penafsiran satu norma atau prinsip yang ada dalam Undang-Undang Dasar yang dikonkretisasi dalam ketentuan undangundang sebagai pelaksanaa tujuan bernegara yang diperintahkan konstitusi. $^{7}$

Dalam Putusan Mahkamah Konstitusi terkait dengan pengujian undang-undang (PUU), manakala Mahkamah Konstitusi memutus suatu undang-undang bertentangan dengan UUD dan menyatakannya tidak memiliki kekuatan mengikat maka putusan tersebut undang-undang tidak hanya mengikat pihak yang mengajukan perkara (inter partes) di Mahkamah Konstitusi, melainkan juga mengikat juga semua warga negara seperti halnya undang-undang mengikat secara umum bagi semua warga negara. Dalam perkara pengujian undang-undang misalnya, yang diuji adalah norma undang-undang yang bersifat abstrak dan mengikat umum. Meskipun dasar permohonan pengujian adalah hak konstitusional pemohon yang dirugikan, namun tindakan tersebut pada dasarnya adalah mewakili kepentingan hukum seluruh masyarakat demi tegaknya konstitusi.

Oleh karena itu, yang terikat oleh putusan Mahkamah Konstitusi tidak hanya dan tidak harus selalu pembentuk undang-undang, tetapi semua pihak yang terkait dengan ketentuan yang diputus

\footnotetext{
${ }^{7} \mathrm{P}$, Stein, “compendium van het burgelijke processrecht-Hukum Acara Perdata, 4edruk, Kluwer, $1997, .158$.
} 
oleh Mahkamah Konstitusi. Atas dasar itulah, maka putusan Mahkamah Konstitusi bersifat erga omnes. Hal tersebut membawa implikasi atau akibat hukum yang sama dengan diundangkannya satu undang-undang yaitu bersifat erga omnes. Itu berarti bahwa putusan tersebut mengkat seluruh warga negara, pejabat negara dan lembaga negara. Selanjutnya bahwa terdapat kewajiban mentaati putusan Mahkamah Konstitusi adalah Hukum memiliki karakter mengatur kepentingan yang bersifat relasional antar manusia. Tujuannya untuk mencapai dan melindungi kepentingan bersama.

Kepentingan yang sifatnya relasional antara manusia ini akan menimbulkan permasalahan dan konflik apabila diserahkan kepada kaidah yang sifatnya subyektif. Keinginan individu dan kelompok yang akan menonjol. Mengabaikan kepentingan dan tujuan bersama. Oleh karena itu, kaidah hukum harus dijaga agar mendapatkan kepercayaan sebagai pengatur kepentingan bersama.

Oleh karena itu, agar hukum mencapai tujuan-tujuan tersebut, maka hukum dibuat untuk ditaati. Ketaatan terhadap hukum akan mengimplikasikan terjadinya ketertiban dalam masyarakat, dan sebaliknya ketidaktaatan terhadap hukum akan mengakibatkan kekacauan. Ketaatan hukum tidak lepas dari kesadaran hukum, dan kesadaran hukum yang baik adalah ketaatan hukum, dan ketidaksadaran hukum yang baik adalah ketidaktaatan. Pernyataan ketaatan hukum harus disandingkan sebagai sebab dan akibat dari kesadaran dan ketaatan hukum.

Pada kenyataannya, ketaatan terhadap hukum tidaklah sama dengan ketaatan sosiallainnya, ketaatan hukum merupakan kewajiban yang harus dilaksanakan dan apabila tidak dilaksanakan akan timbul sanksi, tidaklah demikian dengan ketaatan sosial, ketaatan sosial manakala tidak dilaksanakan atau dilakukan maka sanksi-sanksi sosial yang berlaku pada masyarakat inilah menjadi hakim. Tidaklah berlebihan bila ketaatan di dalam hukum cenderung dipaksakan. Sebagai the supreme law of the land bagi negara dan bangsa Indonesia, UndangUndang Dasar 1945 haruslah dipedomani dan dilaksanakan oleh seluruh elemen negara bangsa ini, baik penyelenggara negara maupun warga negara dalam menunaikan tugas masingmasing.

Dalam posisi semacam itu pula, konstitusi haruslah dapat ditegakkan dan difungsikan sebagai rujukan dalam menemukan solusi untuk menyelesaikan problem-problem kenegaraan dan kebangsaan yang timbul. Dalam hal ini, termasuk dalam upaya membangun kesetiaan terhadap konstitusi adalah ketaatan terhadap putusan Mahkamah Konstitusi karena setiap putusan Mahkamah Konstitusi merupakan cerminan dari konstitusi yang sedang berlangsung.

Gejala ketidaktaatan terhadap putusan Mahkamah Konstitusi mulai marak. Meskipun belum terbukti benar, gejala tersebut misalnya tampak dari adanya kehendak pembuat undangundang untuk memasukkan kembali pasal-pasal yang sebelumnya telah dibatalkan Mahkamah Konstitusi atau bahkan tidak segera membuat dan mengesahkan aturan yang sesuai dengan putusan Mahkamah Konstitusi atau bahkan tidak segera membuat dan mengesahkan aturan yang sesuai dengan putusan Mahkamah Konstitusi. Dalam negara yang demokratis persamaan derajat dan kedudukan warga negara 
dihadapan hukum mejadi tujuan yang harus dicapai sesuai dengan semangat dalam proklamasi kemerdekaan 17 Agustus 1945 yang menjadi tonggak negara hukum Indonesia.

Dihubungkan dengan keadilan memposisikan warga secara sama dihadapan hukum merupakan prisip dari keadilan adalah memperlakukan sama terhadap hal-hal yang sama dan memperlakukan secara berbeda hal-hal yang memang berbeda. Adanya delik aduan dalam Pasal yang berkaitan dengan perlindungan kekuasaan umum atau pemerintah adalah untuk mencegah timbulnya kerugian yang lebih besar manakala negara campur tangan terhadap tindakan atau perbuatan tertentu. Sesuai dengan latar belakang adanya delik aduan yakni melindungi tindakan hukum yang dapat merugikan pihak yang berkepentingan. Prinsip kebebasan berekspresi (freedom of expression) secara proporsional haruslah diutamakan dan memang lebih tinggi nilai hukumnya ketimbang upaya sakralisasi jabatan publik, bahwa KUHP masih terdapat kriminalisasi dan penalisasi terhadap delik penghinaan terhadap penguasa merupakan compatible dan comparable dengan upaya sakrasi jabatan. Secara subtansial hukum pidana nasioal yang berlaku saat ini belum sepenuhnya mengakomodir prinsip-prinsip Hak Asasi Manusia, yang dapat dilihat secara historinya melalui pola kekuasaan kolonialis dengan ciri absolut dan totaliter.

Adanya pembatasan hak berekspresi menambah bukti hukum pidana Indonesia belum menjamin hak-hak setiap individu ${ }^{8}$. Hukum pidana tidak boleh memuat larangan melakukan

8 Dede Kania, Hak Asasi Manusia dalam realitas global, Manggu Makmur Tanjung Lestari, Bandung, 2018, .200. perbuatan yang baik menurut penilaian masyarakat hukum Indonesia. Oleh sebab itu, hukum pidana berfungsi untuk memperkuat dan memperkokoh nilai, asas-asas, norma, dan perbuatan yang baik dengan cara; melarang melakukan perbuatan yang bertentangan atau menyimpang dengan dari norma atau tujuan ideal yang diatur oleh normanorma lain, melarang perbuatan yang mengganggu atau menghalanghalangi orang untuk melakukan perbuatan yang baik atau mencapai tujuan ideal tersebut, melarang orang yang menyalahgunakan kekuasaan atau kewenangan (hak) yang dimilikinya yang sah menurut hukum, dan melarang orang mengganggu hak orang lain yang dijamin oleh hukum. ${ }^{9}$

Sejarah mencatat, Presiden pertama Republik Indonesia pernah dijatuhi pidana penjara, Sukarno yang pernah dipenjara karena dituduh melanggar Pasal 207 KUHP. Bahwa kian bertambahnya zaman akan menambah orang yang menjadi korban Pasal ini dengan dalih membentuk dan melindungi negara sesuai dengan jalannya. Hal demikian diperparah dengan tidak adanya delik aduan yang digunakan pada masa kini sehingga tidak relevan apabila proses pidana masih tetap berjalan tanpa memperdulikan perkembangan zaman, apalagi tidak melaksanakan apa yang telah ditetapkan oleh Mahkamah Konstitusi sebagai pengawal konstitusi dalam putusannya.

Pasal 207 KUHP yang memberikan perlindungan tersendiri kepada pejabatpejabat negara yang sedang menjalankan tugas berdasarkan hukum. Perlunya perlindungan tersendiri terhadap pejabat publik yang sedang menjalankan tugas karena di dalam jabatan dimaksud terkandung di samping unsur subjektif

9 Lihat Putusan Mahkamah Konstitusi No.14/PUU-VI/2008 
pribadi pejabatnya, juga melekat unsur objektif institusinya yang membutuhkan kredibilitas, kewibawaan, dan kapabilitas agar efektif dalam menjalankan tugas publiknya secara mutatis dan mutandis. Semesetinya pelaksanaan Pasal ini dinegasikan sebagai penegasan prinsip persamaan di hadapan hukum, kebebasan mengekspresikan pikiran dan pendapat, kebebasan akan informasi, prinsip kepastian hukum dan prinsip demokrasi. Berdasarkan uraian di atas maka penulis berpendapat bahwa kebebasan berpendapat bukanlah tidak terbatas, batasnya adalah untuk Sejarah mencatat, Presiden pertama Republik Indonesia pernah dijatuhi pidana penjara, Sukarno yang pernah dipenjara karena dituduh melanggar Pasal 207 KUHP.

Bahwa kian bertambahnya zaman akan menambah orang yang menjadi korban Pasal ini dengan dalih membentuk dan melindungi negara sesuai dengan jalannya. Hal demikian diperparah dengan tidak adanya delik aduan yang digunakan pada masa kini sehingga tidak relevan apabila proses pidana masih tetap berjalan tanpa memperdulikan perkembangan zaman, apalagi tidak melaksanakan apa yang telah ditetapkan oleh Mahkamah Konstitusi sebagai pengawal konstitusi dalam putusannya. Pasal 207 KUHP yang memberikan perlindungan tersendiri kepada pejabat-pejabat negara yang sedang menjalankan berdasarkan hukum. Perlunya perlindungan tersendiri terhadap pejabat publik yang sedang menjalankan tugas karena di dalam jabatan dimaksud terkandung di samping unsur subjektif pribadi pejabatnya, juga melekat unsur objektif institusinya yang membutuhkan kredibilitas, kewibawaan, dan kapabilitas agar efektif dalam menjalankan tugas publiknya secara mutatis dan mutandis. Semesetinya pelaksanaan Pasal ini dinegasikan sebagai penegasan prinsip persamaan di hadapan hukum, kebebasan mengekspresikan pikiran dan pendapat, kebebasan akan informasi, prinsip kepastian hukum dan prinsip demokrasi.

Berdasarkan uraian di atas maka penulis berpendapat bahwa kebebasan berpendapat bukanlah tidak terbatas, batasnya adalah untuk memastikan pendapat itu tidak merugikan hak dan kebebasan orang lain. Bahwa hingga kini batas antara kritik dan menghina memerlukan kajian mendalam. Negara tanpa kritik dan pandangan kritik bukanlah negara yang menggaungkan diri sebagai negara hukum demokrasi.

\section{KESIMPULAN}

Berdasarkan kajian dan pembahasan pada bab-bab sebelumnya dapat disimpulkan sebagai berikut:

1. Penerapan Pada kasus Putusan Pengadilan Negeri Jakarta Selatan No.1274/Pid.Sus/2017/PN.Jkt.Sel adalah tidak dilaksanakan delik aduan dalam Pasal 207 KUHP sesuai pertimbanganputusan Mahkamah, pada perkara ini hanya diterapkan delik biasa tanpa adanya pengaduan dari pihak yang merasa dirugikan.

2. Pertimbangan hukum Hakim Pengadilan Negeri Jakarta Selatan menolak pledoi dari penasehat hukum terdakwa dengan menyatakan bahwa judicial review pada putusan Mahkamah Konstitusi tersebut bukanlah Pasal 207 KUHP. Bahwa hakim menerapkan konsep kepastian hukum, tanpa melihat manfaat serta kondisi masyarakat sekarang sehingga berimpikasi pada ketidakadilan dalam putusan. Dengan konsep demikian akan menjadi biasnya penerapan delik 
padal Pasal 207 KUHP terutama yang akan diterapkan oleh aparat penegak hukum.

3. Analisis kasus dalam Pasal 207 KUHP tidak diterpakan delik aduan adalah sebagai berikut:

a. Setiap warga, pemerintah dan lembaga negara wajib mengikuti putusan Mahkamah Konstitusi sebagai pengawal konstitusi

b. Adanya Pasal 207 KUHP yang tidak diterapkan delik aduannya akan digunakan sebagai alat kriminalisasi terhadap warga negara, pemerintah akan dengan mudah menggunakan Pasal ini dengan dalih penghinaan untuk menyerang pihak oposisi yang bertujuan mengkritik jalannya pemerintahan guna membangun stabilitas kehidupan berbangsa dan bernegara.

\section{DAFTAR PUSTAKA}

\section{Buku:}

Andi Hamzah, Hukum Acara Pidana Indonesia, Sinar Grafika, Jakarta, 2014.

Dede Kania, Hak Asasi Manusia dalam realitas global, Manggu Makmur Tanjung Lestari, Bandung, 2018.

Mardjono Reksodiputro, Sistem Peradilan Pidana Indonesia, Pusat Keadilan dan Pengabdian Hukum UI, Jakarta, 1993.
Ni'matul Huda, Kekuatan Eksekutorial Putusan Mahkamah Konstitusi, FH UII Press, Yogyakarta, 2018

$\mathrm{P}$, Stein, “compendium van het burgelijke processrecht-Hukum Acara Perdata, 4edruk, Kluwer, 1997.

Peraturan Perundang-Undangan:

UUD NRI Tahun 1945

Undang-Undang No.1 Tahun

1946 Tentang Peraturan

Hukum Pidana

Putusan Pengadilan:

Putusan Mahkamah Konstitusi No.013022-2006

Putusan Mahkamah Konstitusi No. 31/PUU-XIII-2015

Putusan Pengadilan Negeri Jakarta Selatan

No.1274/Pid.Sus/2017/PN.Jk t.Sel

Sumber Lainnya:

ELSAM, ICJR, IMDLN, PBHI dan YLBHI, Pidana Penghinaan adalah Pembatasan Kemerdekaaan Berpendapat yang Inkonstitusional, Brefing Paper No.2, 2010. Valerian Itu Varis, Delik aduan dalam pasal penghinaan ITE, Diakses Melalui: $<$ https://www.kompasiana.co $\mathrm{m} / \mathrm{valerianl}$ ibertwangge/58173faccb23bd 7c33e6437 0/delik-aduandalampasal-penghinaan- uuite? page $=$ all $>, \quad$ Diunduh Pada Tanggal 12 Februari 2019, Pukul 7.24 WIB. 